\title{
EMERGY ANALYSIS AND ENVIRONMENTAL INDICES APPLIED TO A COMPANY PRODUCING ALUMINIUM EXTRUDED BARS
}

\author{
G. SIRACUSA, A.D. LA ROSA, A. AIELLO \& V. SIRACUSA \\ Department of Physical and Chemical Methodology for Engineering, University of Catania, Italy.
}

\begin{abstract}
In this paper we apply two methodologies to a company that produces aluminium extruded bars: (1) the "pollutant interaction matrix method', which allows the calculation of a global environmental protection index (Ep) in order to verify the eco-compatibility of the industrial activity, and (2) emergy analysis, a methodology used to evaluate the sustainability of an activity. The first methodology, which is applied to evaluate the environmental pollution risk, requires defining, for the whole industrial process, sectors of activities (defined as construction sites where activities of the same type are carried out) and a set of parameters $(t=$ duration of pollution effect, $P=$ quantity of pollutant produced, $G=$ hazard of the pollutant) for each activity. Furthermore, to obtain information on the environmental cost of the whole industrial process, in terms of use of resources (fuel, electricity, water, etc.) we apply the emergy methodology as a complementary index for a global evaluation of sustainability. The environmental index results show that although the evaluated $\mathrm{Ep}_{\text {ratio }}$ has a very low value (0.18), indicating that the whole process is non-polluting, some activities of the industrial process generate local pollution which could be dangerous for the workers' health. The emergy analysis indicates that the most remarkable emergy flows are mainly associated with the use of aluminium panels and the consumption of electricity and methane.
\end{abstract}

Keywords: aluminium extruded bars, emergy per unit, pollution risk, sustainability indicators.

\section{INTRODUCTION}

Production process externalities are the costs imposed on society and the environment, which are not included in the market price. They include damage to the natural and built environment, such as the effects of air pollution on health, buildings, crops, forests and global warming, occupational disease and accidents, and reduced amenity from visual intrusion of plants or emissions of noise. Traditional economic assessment of production processes has tended to ignore these effects; however, there is a growing interest in adopting a more sophisticated approach involving the quantification of these environmental and health impacts of energy and material use and their related external costs. For this purpose the International Standardization Organization (ISO) 9000/14000 and Eco-Management and Audit Scheme (EMAS) norms have been introduced [1,2]; not only must products be in conformity with the ISO and EMAS requirements but the process is also required to guarantee the continuity of production by avoiding the risk of stopping the plant because of environmental violations and/or the occurrence of accidents. Environmental indices have been studied to track and understand ecosystems [3-6]. In this paper an integrated approach is proposed using:

1. a methodology to evaluate the environmental pollution risk of a company [7] that produces aluminium bars by means of the environmental protection index (Ep);

2. an ecological indicator, emergy analysis, to evaluate the environmental cost.

\subsection{Model implementation}

\section{EVALUATION OF THE ENVIRONMENTAL PROTECTION INDEX (Ep)}

The whole industrial productive cycle is described in Fig.1 


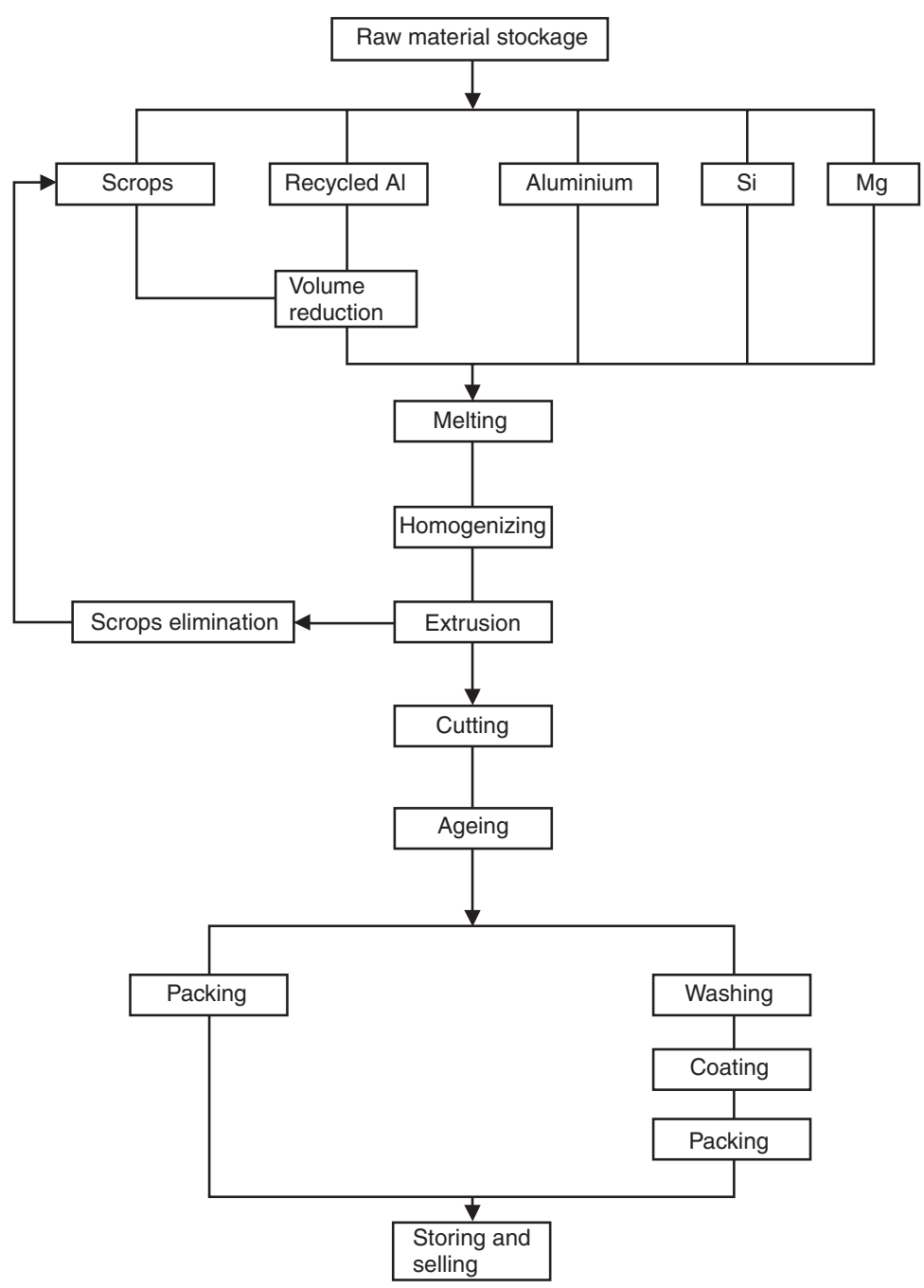

Figure 1: Description of the productive cycle.

The industrial building is divided into three sectors:

- Sector A: Foundry

- Sector B: Extrusion process

- Sector C: Coating and packing

Each sector is characterized by a set of 'variable parameters' $(t, G, P)$ that are defined below:

- $t$ is the duration (in hours) of pollution; the values range from 0 to 1 and correspond to $1 / 24$ of the duration of the polluting effect for a determined activity; the reference unit is a working day of $24 \mathrm{~h}$ including fractions.

- $G$ expresses the hazard of the pollutant; it depends on the severity of the consequences due to the specific pollutant.

- $P$ is derived from the amount of pollutant thrown into the environment. 
Table 1: Evaluation of parameters $P$ and $G$ by considering the amount of pollutants produced and the health risk involved.

\begin{tabular}{lll}
\hline$P$ and $G$ values & \multicolumn{1}{c}{$P$} & \multicolumn{1}{c}{$G$} \\
\hline 0 & Absence of pollutant & No pollution \\
0.1 & $\begin{array}{l}\text { Very low production of pollutant, no } \\
\text { hazard } \\
\text { Low production of pollutant, no } \\
\text { hazard }\end{array}$ & Limited and controlled pollution \\
0.25 & $\begin{array}{l}\text { Remarkable production of pollutant, } \\
\text { no hazard }\end{array}$ & Remarkable but controlled pollution \\
0.50 & $\begin{array}{l}\text { High production of pollutant } \\
0.75\end{array}$ & $\begin{array}{l}\text { Remarkable pollution, not controllable, } \\
\text { health risk }\end{array}$ \\
1 & $\begin{array}{l}\text { Very high production of pollutant } \\
\text { (limit of law) }\end{array}$ & $\begin{array}{l}\text { highollution, irreversible, severe } \\
\text { health risk }\end{array}$ \\
\hline
\end{tabular}

Table 1 lists the data for the evaluation of parameters $G$ and $P$, with reference to each sector. For each type of pollution, it is possible to determine the hazard and the pollutant indices whose values are included in the range $0-1$.

The product of the factors $t, G$ and $P$ gives an index of pollution $Y$ which refers to a specific operation as well as a specific type of pollution:

$$
t \times G \times P=Y \text { sector/material/type of pollution. }
$$

If there is no interaction, the result will be $Y=0$.

If we consider each operation related to the raw material aluminium (Al) in sector A, it is possible to evaluate several indices of environmental pollution as follows:

$$
Y_{\mathrm{A} / \mathrm{Al} / \mathrm{air}}, Y_{\mathrm{A} / \mathrm{Al} / \text { water }}, Y_{\mathrm{A} / \mathrm{Al} / \text { soil }}, Y_{\mathrm{A} / \mathrm{Al} / \text { acoustic }} \text {, etc. }
$$

This procedure is applied to all the raw materials and to all the operations in sector A in order to obtain more indices $Y_{\mathrm{A} / i / \text { air }}, Y_{\mathrm{A} / i \text { water }}, Y_{\mathrm{A} / i / \text { soil }}, Y_{\mathrm{A} / i / \text { acoustic }}$, etc. (where $i$ indicates a material or an operation), which allows the evaluation of a 'matrix of process pollutants' that lists the material involved in rows and the type of pollution in columns (Table 2). In accordance with this procedure, the pollution index $\left(Y_{L}\right)$ value referring to each type of pollutant and each raw material in sector $\mathrm{A}$ is calculated as a summation by columns. Each obtained value represents the numerical measure of the environmental sustainability of the different operations in sector A. The same procedure should be applied to all sectors in order to obtain a new matrix, shown in Table 3, called 'polluting processes matrix' where the elements are given by all the $Y_{L}$ values evaluated previously. The sum of elements contained in the rows of the 'polluting processes matrix' (see Tables 3 and 7) gives, for each homogeneous sector, an index $L_{\text {sector. }}$. For each sector it is possible to evaluate two values of $L: L_{\max }$ (which is a theoretical value corresponding to $G, P$ and $t$ values $=1$ for each polluting process) and $L_{\text {exp }}$ (which is the effective $L$ value calculated based on the number and intensity of the polluting processes occurring in each sector). Areas characterized by processes with high hazard potential ( $L_{\text {exp }}$ close $\left.L_{\max }\right)$ require urgent action on the productive layout. 
Table 2: Matrix of process pollutants for sector A.

\begin{tabular}{lcccccc}
\hline & Air & Water & Soil & Acoustic & $\ldots$ & $\ldots$ \\
\hline Material 1 & $Y_{\mathrm{A} / 1 / \text { air }}$ & $Y_{\mathrm{A} / 1 / \text { water }}$ & $Y_{\mathrm{A} / 1 / \text { soil }}$ & $Y_{\mathrm{A} / 1 / \text { acoustic }}$ & $Y_{\mathrm{A} / 1 / \ldots}$ & $\ldots$ \\
Material 2 & $Y_{\mathrm{A} / 2 / \text { air }}$ & $Y_{\mathrm{A} / 2 / \text { water }}$ & $Y_{\mathrm{A} / 2 / \text { soil }}$ & $Y_{\mathrm{A} / 2 / \text { acoustic }}$ & $Y_{\mathrm{A} / 2 / \ldots}$ & $\cdots$ \\
Material 3 & $Y_{\mathrm{A} / 3 / \text { air }}$ & $Y_{\mathrm{A} / 3 / \text { water }}$ & $\cdots$ & $\cdots$ & $\cdots$ & $\cdots$ \\
Material 4 & $\cdots$ & $\cdots$ & $Y_{\mathrm{A} / 4 / \text { soil }}$ & $Y_{\mathrm{A} / 4 / \text { acoustic }}$ & $\cdots$ & $\cdots$ \\
$\ldots$ & $\cdots$ & $\cdots$ & $\ldots$ & $\ldots$ & $\ldots$ & $\ldots$ \\
Sector A & $\Sigma Y_{\mathrm{A} / i / \text { air }}$ & $\Sigma Y_{\mathrm{A} / i / \text { water }}$ & $\Sigma Y_{\mathrm{A} / i / \text { soil }}$ & $\Sigma Y_{\mathrm{A} / i / \text { acoustic }}$ & $\Sigma Y_{\mathrm{A} / i / \ldots}$ & $\Sigma Y_{\mathrm{A} / i / \ldots}$ \\
& $=Y_{L / \mathrm{A} / \text { air }}$ & $=Y_{L / \mathrm{A} / \text { water }}$ & $=Y_{L / \mathrm{A} / \text { soil }}$ & $=Y_{L / \mathrm{A} / \text { acoustic }}$ & $=Y_{L / \mathrm{A} / \ldots}$ & $=Y_{L / \mathrm{A} / \ldots}$ \\
& & & & & &
\end{tabular}

Table 3: Matrix of polluting processes considering all the homogeneous sectors.

\begin{tabular}{lccccc}
\hline & Air & Water & Soil & Acoustic & $\ldots$ \\
\hline Sector A & $\ldots$ & $Y_{L / \mathrm{A} / \text { water }}$ & $Y_{L / \mathrm{A} / \text { soil }}$ & $Y_{L / \mathrm{A} / \text { acoustic }}$ & $Y_{L / \mathrm{A} / \ldots}$ \\
Sector B & $Y_{L / \mathrm{B} / \mathrm{air}}$ & $Y_{L / \mathrm{B} / \text { water }}$ & $Y_{L / \mathrm{B} / \text { soil }}$ & $Y_{L / \mathrm{B} / \text { acoustic }}$ & $Y_{L / \mathrm{B} / \ldots}$ \\
Sector C & $Y_{L / \text { C/air }}$ & $Y_{L / \mathrm{C} / \text { water }}$ & $\ldots$ & $\ldots$ & $\ldots$ \\
Sector D & $\ldots$ & $\ldots$ & $Y_{L / \mathrm{D} / \text { soil }}$ & $Y_{L / \mathrm{D} / \text { acoustic }}$ & $\ldots$ \\
$\ldots$ & $\ldots$ & $\ldots$ & $\cdots$ & $\cdots$ & $\ldots$ \\
\hline
\end{tabular}

The sum by column of the elements of the matrix of the polluting processes gives, for each column, an index $R$ which represents the amount of pollutant for each type of pollution (Tables 3 and 7).

The sum by row of the different values of $L_{\exp }$ gives a resulting value called 'index of environmental protection':

$$
\sum_{i=\text { sector A }}^{\text {sector } \mathrm{N}} L_{i}=\mathrm{Ep}_{\mathrm{exp}} .
$$

The sum of the different values of $L_{\max }$ gives a resulting value called maximum index, Ep $\mathrm{p}_{\max }$.

The ratio $\mathrm{Ep}_{\text {ratio }}=\mathrm{Ep}_{\mathrm{exp}} / \mathrm{Ep}_{\max }$ indicates the sustainability of the whole productive cycle by means of the relation:

$$
0 \leq \mathrm{Ep}_{\text {ratio }} \leq 1,
$$

where 0 refers to a totally sustainable process and 1 means that the process is totally unsustainable.

As a consequence of the values obtained and the immediate identification of the most polluted sectors and operations, companies can decide whether and how to intervene so as to improve the environmental performance, as described in Fig. 2. A reiterative application of the method gives an evaluation of the efficiency of the chosen remedy.

There are considerable differences between the behaviour of the smallest and the largest particles within our range of interest, roughly from molecular sizes up to $103 \mu \mathrm{m}$. The smaller particles closely follow the motion of the surrounding gas and may remain airborne almost indefinitely, while the larger particles have an appreciable acceleration under gravity and are relatively easy to precipitate. 


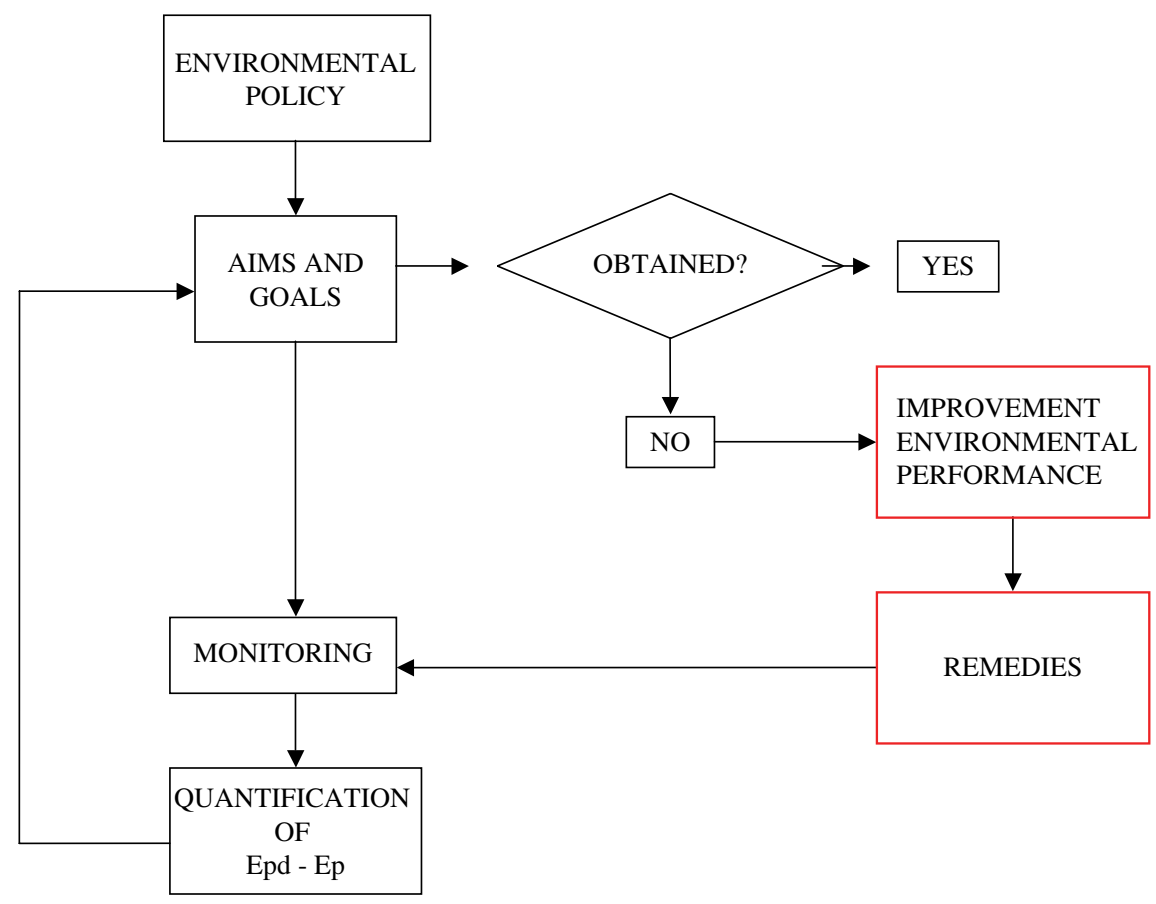

Figure 2: Scheme of the company environmental performance.

Nevertheless, large grains of dust are transported for many miles under favourable atmospheric conditions.

\subsection{Construction of the 'matrix of polluting processes'}

For each sector, several types of pollution (air pollution, acoustic pollution, dust production, solid waste production, chemical discharge in sewage, vibrations, thermal pollution, gas production) were considered as reported below.

Sector A (Foundry): The operations involved in this sector are described below and the results obtained are reported in Table 4.

- Raw materials and scraps collection and stockage: The operation involves two types of pollution: air pollution and solid waste production. The stocking area is full $24 \mathrm{~h}$ a day $(t=1)$, produces very low quantities of dust and solid particles in the atmosphere $(P=0.1)$ consequently with limited and controlled air pollution $(G=0.1)$.

- Volume reduction: The raw materials are ground by means of a mechanical device to a size of $30 \mathrm{~cm}$. The duration of the operation is $18 \mathrm{~h}(t=0.66)$ and the main types of pollution are dust, acoustic pollution and vibrations in remarkable but controlled production $(P$ and $G=0.5)$.

- Melting operation: The ground aluminium chips are transported by a conveyor belt to an oven heated at a temperature of $720-740^{\circ} \mathrm{C}$ by a combination of electric power and methane combustion. After cooling, the aluminium bars are cut to the required size. The duration of the operation is $18 \mathrm{~h}$ $(t=0.66)$ and the consequent types of pollution are: remarkable but controlled gas production 
Table 4: Calculation of the pollution indices $Y_{L}$ for sector A (foundry).

\begin{tabular}{|c|c|c|c|c|c|c|c|c|}
\hline Operation & Pollution & $t$ & $G$ & $P$ & $Y_{\mathrm{A}}$ & $Y_{i}$ & Pollution & $Y_{L}$ \\
\hline \multirow{2}{*}{$\begin{array}{l}\text { Raw materials and } \\
\text { scraps collection }\end{array}$} & Air pollution & 1 & 0.1 & 0.1 & 0.01 & 0.01 & Air pollution & 0.175 \\
\hline & Solid waste & & 0.1 & 0.1 & 0.01 & 0.01 & Gas production & 0.18 \\
\hline \multirow[t]{3}{*}{ Volume reduction } & Dust production & 0.66 & 0.5 & 0.5 & 0.25 & 0.165 & Acoustic pollution & 0.165 \\
\hline & Acoustic & & 0.5 & 0.5 & 0.25 & 0.165 & Thermal pollution & 0.07 \\
\hline & Vibrations & & 0.5 & 0.5 & 0.25 & 0.165 & Dust production & 0.165 \\
\hline \multirow[t]{3}{*}{ Melting } & Gas production & 0.66 & 0.5 & 0.5 & 0.25 & 0.165 & Solid waste & 0.05 \\
\hline & Air pollution & & 0.5 & 0.5 & 0.25 & 0.165 & production & 0.165 \\
\hline & $\begin{array}{l}\text { Thermal } \\
\text { pollution }\end{array}$ & & 0.1 & 0.75 & 0.075 & 0.049 & Vibrations & \\
\hline \multirow[t]{3}{*}{ Homogenizing } & Solid waste & 0.66 & 0.25 & 0.25 & 0.0625 & 0.04 & & \\
\hline & Gas production & & 0.25 & 0.1 & 0.025 & 0.0165 & & \\
\hline & $\begin{array}{l}\text { Thermal } \\
\text { pollution }\end{array}$ & & 0.1 & 0.25 & 0.025 & 0.0165 & & \\
\hline
\end{tabular}

$\left(\mathrm{CO}_{x}, \mathrm{NO}_{x}\right)$ and air pollution $(P$ and $G=0.5)$, high but without consequence thermal pollution $(P=0.75, G=0.1)$ and low solid waste production $(P$ and $G=0.25)$.

- Homogenizing: Before the extrusion process, the aluminium bars require a homogenizing treatment (heated at $530^{\circ} \mathrm{C}$ for $12 \mathrm{~h}$ in a secondary oven). This operation produces gas and low quantity of thermal pollution.

Sector B (Extrusion process): The operations are described below.

- Extrusion: The aluminium bars are pre-heated at the temperature of $450^{\circ} \mathrm{C}$, cut into smaller pieces and transported to the extruder where the material passes through a press. During this operation thermal pollution, acoustic pollution and vibrations occur.

- Cutting: The extruded bar is cut to the required dimensions by a squaring shear creating dust production and acoustic pollution.

- Ageing and cooling: The extruded bars obtained are transported to another oven where an ageing treatment, in order to improve the mechanical properties, is carried out. Vibrations, thermal pollution and acoustic pollution occur.

$P, G, t$ and $Y_{L}$ values relative to all the operations involved in this sector are reported in Table 5 .

\section{Sector C (Coating and packing):}

- Washing: This operation is required to perfectly clean the surface of the aluminium bars in order to obtain a good coating. Different chemical solutions are used following the sequence: (1) sodium hydroxide, (2) water, (3) acidic solutions, (4) water, (5) nitric acid and chromic acid solutions, (6) water. During the washing operation, high concentrations of chemicals, with controlled pollution, are discharged.

- Coating: After drying, the bars are coated by the electrostatic method which involves the induced deposition of very fine solid particles of enamel (previously electrically positive charged) on the aluminium bars (previously negative charged). After the deposition, the bars are heated in an oven at $180^{\circ} \mathrm{C}$. Vibrations, air pollution, acoustic pollution and dust production occur. 
Table 5: Calculation of the pollution indices $Y_{L}$ for sector B (extrusion process).

\begin{tabular}{llccccccl}
\hline Operation & \multicolumn{1}{c}{ Pollutant } & $t$ & $G$ & $P$ & $Y_{\mathrm{B}}$ & \multicolumn{1}{c}{$Y_{i}$} & \multicolumn{1}{c}{ Pollution } & $Y_{L}$ \\
\hline Extrusion & Thermal pollution & 1 & 0.1 & 0.1 & 0.01 & 0.01 & Acoustic pollution & 0.375 \\
& Acoustic pollution & & 0.5 & 0.25 & 0.125 & 0.125 & Thermal pollution & 0.015 \\
& Vibrations & & 0.5 & 0.5 & 0.25 & 0.25 & Dust production & 0.25 \\
Cutting & Dust production & 1 & 0.5 & 0.5 & 0.25 & 0.25 & Vibrations & 0.3125 \\
& Acoustic pollution & & 0.5 & 0.25 & 0.125 & 0.125 & & \\
Ageing and & Vibrations & 0.5 & 0.5 & 0.25 & 0.125 & 0.0625 & \\
cooling & Thermal pollution & & 0.1 & 0.1 & 0.01 & 0.005 & \\
& Acoustic pollution & & 0.5 & 0.5 & 0.25 & 0.125 & & \\
\hline
\end{tabular}

Table 6: Calculation of the pollution indices $Y_{L}$ for sector $\mathrm{C}$ (coating and packing).

\begin{tabular}{|c|c|c|c|c|c|c|c|c|}
\hline Operation & Pollutant & $t$ & $G$ & $P$ & $Y_{\mathrm{C}}$ & $Y_{i}$ & Pollution & $Y_{L}$ \\
\hline \multirow[t]{3}{*}{ Washing } & Air pollution & 1 & 0.25 & 0.5 & 0.125 & 0.125 & Air pollution & 0.3125 \\
\hline & Chemical discharge & & 0.5 & 0.75 & 0.375 & 0.375 & Acoustic pollution & 0.125 \\
\hline & in sewage & & & & & & Dust production & 0.25 \\
\hline \multirow[t]{3}{*}{ Coating } & Air pollution & 1 & 0.25 & 0.75 & 0.1875 & 0.1875 & Solid waste & 0.025 \\
\hline & Acoustic pollution & & 0.5 & 0.25 & 0.125 & 0.125 & production & \\
\hline & Dust production & & 0.5 & 0.5 & 0.25 & 0.25 & Chemical discharge & 0.375 \\
\hline Packing & $\begin{array}{l}\text { Solid waste } \\
\text { production }\end{array}$ & 1 & 0.25 & 0.1 & 0.025 & 0.025 & in sewage & \\
\hline
\end{tabular}

- Packing and solid waste production: This is the last operation of the process. The coated bars are packed using paper sheets and stored. Solid wastes are produced.

The results obtained for sector $\mathrm{C}\left(t, P, G\right.$ and $\left.Y_{L}\right)$ are reported in Table 6 .

The contribution of each type of pollution for each sector is reported in the matrix of the polluting processes in Table 7.

The comparison between the various indices is useful because even though the whole process seems to be sustainable $\left(\mathrm{Ep}_{\max }=17 ; \mathrm{Ep}_{\exp }=3.12 ; \mathrm{Ep}_{\text {ratio }}=0.18\right)$, there are some operations, such as extrusion, coating, washing, packing, that involve pollutant production: during the coating operation there is a remarkable production of dust $\left(Y_{\mathrm{C} / \text { dust production }}=0.25\right.$, Table 6); during the washing operation chemicals are discharged in sewage $\left(Y_{\mathrm{C} / \text { chem. disch. }}=0.375\right.$, Table 6$)$; during the extrusion operation vibrations occur $Y_{\mathrm{B} / \text { vibration }}=0.25$, Table 5).

Table 7 allows the immediate identification of the most significant pollutants for each sector. If we compare the $L_{i}$ values for sectors A and B ( 0.95 and 0.98 , respectively), we can see that in sector A there are more pollutants which influence to a lesser degree because of the smaller values of $\left(Y_{L}=0.17,0.18,0.16,0.07,0.16,0.0 ; 0.16\right)$, while in sector B the $Y_{L}$ values are higher $\left(Y_{L}=0.375\right.$, $0.25,0.3125)$. Specifically, the value $Y_{L}=0.375$, which is significantly high, could influence the company in its decision on what action to take to improve the environmental efficiency and thereby obtain the environmental quality certification. 


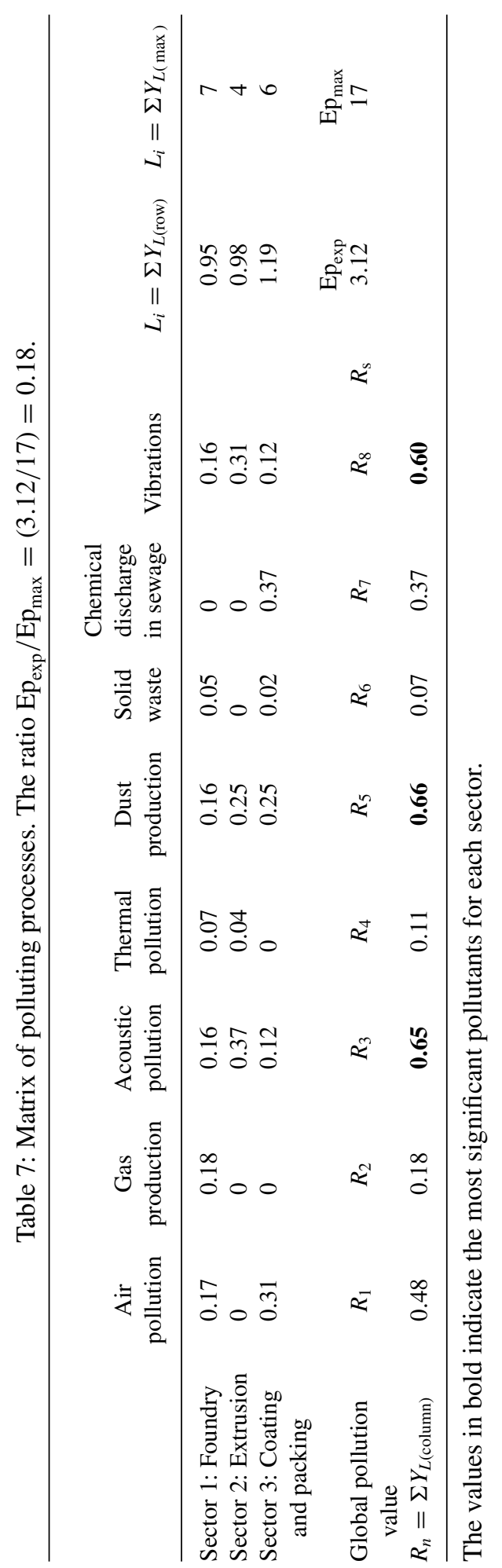




\section{ECOLOGICAL INDICATOR: EMERGY ANALYSIS}

\subsection{Evaluation of the emergy flows}

Emergy is an expression of all the energy (and resources) used in the work processes that generate a product or service and is expressed as units of one type of energy [8]. In the most general sense, the total emergy driving a process is a measure of the activities required and converged to make that process possible. It is a measure of work (in both the past and the present) necessary to provide a given resource or service $[9,10]$. To evaluate the quality of the energy flows, transformities can be calculated and compared with other energy forms. The solar transformity of services and products generated by the system under study is obtained by dividing the total emergy input required by the energy of the product or service. Figure 3 shows a diagram of emergy flows involved in the whole process. Renewable and non-renewable resources are supposed to act in the system where they enter from the left in the diagram, transformations occur inside and products are obtained on the right. Tables 8-10 report the emergy values for the foundry, the extrusion process and the coating process, respectively. The transformities used for the calculations are mainly found in the literature as reported in Appendix A. The calculation procedure adopted for the foundry process is given in Appendix B; for the other two processes similar relations were used.

\subsection{Emergy results}

Results of emergy analysis are reported in Tables 8-10. Column 1 is the name of the item involved in the process; column 2 is the raw data in joules, grams or euros, usually evaluated as flux per year;

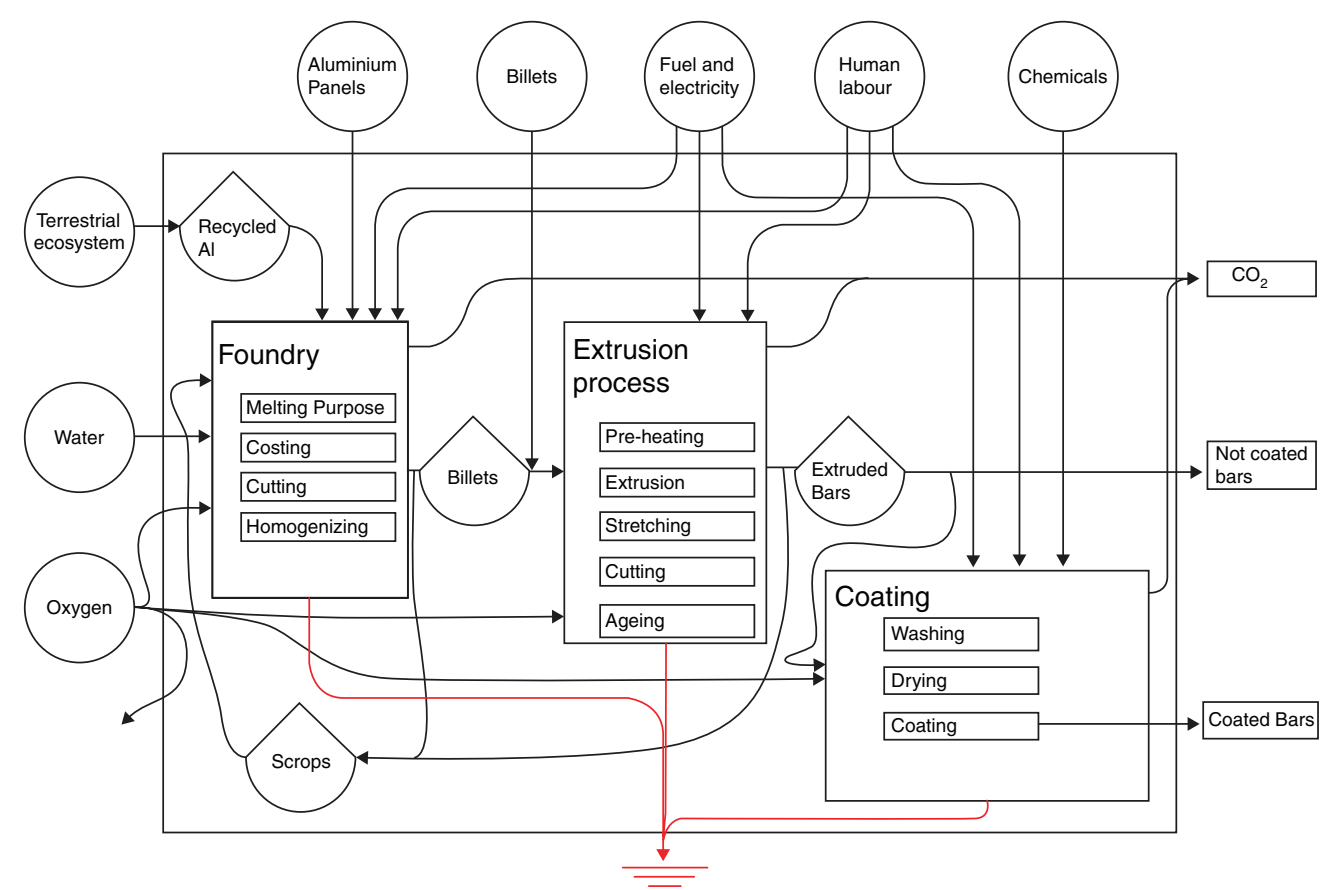

Figure 3: Diagram of emergy flows. 
Table 8: Evaluation of the emergy flows for the foundry.

\begin{tabular}{lccc}
\hline $\begin{array}{l}\text { Item } \\
\text { Quantity per year } \\
(\mathrm{J}, \mathrm{g}, €)\end{array}$ & $\begin{array}{c}3 \\
\text { Emergy per unit } \\
\text { (sej/unit) }\end{array}$ & $\begin{array}{c}4 \\
\text { Emergy flow } \\
\text { (sej/year) }\end{array}$ \\
\hline Electricity & $1.89 \mathrm{E} 12 \mathrm{~J}$ & $1.43 \mathrm{E} 5 \mathrm{sej} / \mathrm{J}$ & $2.70 \mathrm{E} 17 \mathrm{sej}$ \\
Human labour & $2.80 \mathrm{E} 10 \mathrm{~J}$ & $7.38 \mathrm{E} 6 \mathrm{sej} / \mathrm{J}$ & $2.07 \mathrm{E} 17 \mathrm{sej}$ \\
Methane & $3.55 \mathrm{E} 13 \mathrm{~J}$ & $4.80 \mathrm{E} 4 \mathrm{sej} / \mathrm{J}$ & $1.70 \mathrm{E} 18 \mathrm{sej}$ \\
Recycled aluminium & $3.58 \mathrm{E} 9 \mathrm{~g}$ & $12.53 \mathrm{E} 9 \mathrm{sej} / \mathrm{g}$ & $4.48 \mathrm{E} 19 \mathrm{sej}$ \\
Aluminium panels & $2.49 \mathrm{E} 9 \mathrm{~g}$ & $12.53 \mathrm{E} 9 \mathrm{sej} / \mathrm{g}$ & $3.12 \mathrm{E} 19 \mathrm{sej}$ \\
Aluminium scraps from & $1.16 \mathrm{E} 9 \mathrm{~g}$ & $12.53 \mathrm{E} 9 \mathrm{sej} / \mathrm{g}$ & $1.45 \mathrm{E} 19 \mathrm{sej}$ \\
$\quad$ billets & & & \\
Aluminium scraps from & $0.30 \mathrm{E} 9 \mathrm{~g}$ & $12.53 \mathrm{E} 9 \mathrm{sej} / \mathrm{g}$ & $3.75 \mathrm{E} 18 \mathrm{sej}$ \\
$\quad$ draw pieces & & & \\
Other materials* & $2.30 \mathrm{E} 7 \mathrm{~g}(42,735 €)$ & $1.4 \mathrm{E} 12 \mathrm{sej} / €$ & $5.98 \mathrm{E} 16 \mathrm{sej}$ \\
Water & $3.23 \mathrm{E} 9 \mathrm{~g}$ & $3.40 \mathrm{E} 5 \mathrm{sej} / \mathrm{g}$ & $1.09 \mathrm{E} 15 \mathrm{sej}$ \\
Oxygen & $2.56 \mathrm{E} 9 \mathrm{~g}$ & $5.16 \mathrm{E} 7 \mathrm{sej} / \mathrm{g}$ & $1.32 \mathrm{E} 17 \mathrm{sej}$ \\
Maintenance cost & $9.50 \mathrm{E} 3 € \mathrm{E}$ & $1.4 \mathrm{E} 12 \mathrm{sej} / €$ & $1.33 \mathrm{E} 16 \mathrm{sej}$ \\
Plant construction cost & $2.15 \mathrm{E} 5 €$ & $1.4 \mathrm{E} 12 \mathrm{sej} / €$ & $3.02 \mathrm{E} 17 \mathrm{sej}$ \\
Total emergy for billets & $7.14 \mathrm{E} 9 \mathrm{~g}$ & $1.35 \mathrm{E} 10 \mathrm{sej} / \mathrm{g}$ & $9.68 \mathrm{E} 19 \mathrm{sej}$ \\
$\quad$ production & & & \\
\hline
\end{tabular}

*Other materials:

Magnesium consumed $=1.15 \mathrm{E} 7 \mathrm{~g} /$ year; $\mathrm{Mg}$ cost $=0.0015 € / \mathrm{g} ; \mathrm{Mg}$ total cost $=17325 € /$ year.

Silicon consumed $=1.15 \mathrm{E} 7 \mathrm{~g} /$ year; $\mathrm{Si}$ cost $=0.0022 € / \mathrm{g} ;$ Si total cost $=25410 € /$ year.

Total cost $=42735 € /$ year for $2.30 \mathrm{E} 7 \mathrm{~g}$ of materials.

Table 9: Evaluation of the emergy flows for the extrusion process.

\begin{tabular}{lccc}
\hline $\begin{array}{l}\text { Item } \\
\text { Quantity per year } \\
(\mathrm{J}, \mathrm{g}, €)\end{array}$ & $\begin{array}{c}3 \\
\text { Emergy per unit } \\
\text { (sej/unit) }\end{array}$ & $\begin{array}{c}4 \\
\text { Emergy flow } \\
\text { (sej/year) }\end{array}$ \\
\hline Electricity & $1.01 \mathrm{E} 13 \mathrm{~J}$ & $1.43 \mathrm{E} 5 \mathrm{sej} / \mathrm{J}$ & $1.44 \mathrm{E} 18 \mathrm{sej}$ \\
Human labour & $9.16 \mathrm{E} 10 \mathrm{~J}$ & $7.38 \mathrm{E} 6 \mathrm{sej} / \mathrm{J}$ & $6.76 \mathrm{E} 17 \mathrm{sej}$ \\
Methane & $1.82 \mathrm{E} 13 \mathrm{~J}$ & $4.80 \mathrm{E} 4 \mathrm{sej} / \mathrm{J}$ & $8.73 \mathrm{E} 17 \mathrm{sej}$ \\
Billets & $5.97 \mathrm{E} 9 \mathrm{~g}$ & $1.35 \mathrm{E} 10 \mathrm{sej} / \mathrm{g}$ & $8.06 \mathrm{E} 19 \mathrm{sej}$ \\
Billets from others & $1.66 \mathrm{E} 9 \mathrm{~g}$ & $1.35 \mathrm{E} 10 \mathrm{sej} / \mathrm{g}$ & $2.24 \mathrm{E} 19 \mathrm{sej}$ \\
Oxygen & $1.31 \mathrm{E} 9 \mathrm{~g}$ & $5.16 \mathrm{E} 7 \mathrm{sej} / \mathrm{g}$ & $6.75 \mathrm{E} 16 \mathrm{sej}$ \\
Maintenance cost & $9.50 \mathrm{E} 3 €$ & $1.4 \mathrm{E} 12 \mathrm{sej} / €$ & $1.33 \mathrm{E} 16 \mathrm{sej}$ \\
Plant construction cost & $2.74 \mathrm{E} 5 €$ & $1.4 \mathrm{E} 12 \mathrm{sej} / €$ & $3.84 \mathrm{E} 17 \mathrm{sej}$ \\
Sodium aluminate* & $2.0 \mathrm{E} 7 \mathrm{~g}$ & $1.4 \mathrm{E} 12 \mathrm{sej} / €$ & $1.96 \mathrm{E} 16 \mathrm{sej}$ \\
Total emergy for extrusion & $7.64 \mathrm{E} 9 \mathrm{~g}$ & $1.39 \mathrm{E} 10 \mathrm{sej} / \mathrm{g}$ & $10.63 \mathrm{E} 19 \mathrm{sej}$ \\
\multicolumn{1}{c}{ products } & & & \\
\hline
\end{tabular}

${ }^{*}$ Sodium aluminate treatment cost $=1.4 \mathrm{E} 4 € /$ year for $2.0 \mathrm{E} 7 \mathrm{~g}$ of material per year. 
Table 10: Evaluation of the emergy flows for the coating sector.

\begin{tabular}{lccc}
\hline & $\begin{array}{c}2 \\
\text { Quantity per year } \\
(\mathrm{J}, \mathrm{g}, €)\end{array}$ & $\begin{array}{c}3 \\
\text { Emergy per unit } \\
\text { (sej/unit) }\end{array}$ & $\begin{array}{c}4 \\
\text { Emergy flow } \\
\text { (sej/year) }\end{array}$ \\
\hline Electricity & $1.87 \mathrm{E} 12 \mathrm{~J}$ & $1.43 \mathrm{E} 5 \mathrm{sej} / \mathrm{J}$ & $2.67 \mathrm{E} 17 \mathrm{sej}$ \\
Human labour & $4.33 \mathrm{E} 10 \mathrm{~J}$ & $7.38 \mathrm{E} 6 \mathrm{sej} / \mathrm{J}$ & $3.19 \mathrm{E} 17 \mathrm{sej}$ \\
Methane & $5.70 \mathrm{E} 12 \mathrm{~J}$ & $4.80 \mathrm{E} 4 \mathrm{sej} / \mathrm{J}$ & $2.73 \mathrm{E} 17 \mathrm{sej}$ \\
Extruded bars & $2.39 \mathrm{E} 9 \mathrm{~g}$ & $1.39 \mathrm{E} 10 \mathrm{sej} / \mathrm{g}$ & $3.32 \mathrm{E} 19 \mathrm{sej}$ \\
Oxygen & $0.41 \mathrm{E} 9 \mathrm{~g}$ & $5.16 \mathrm{E} 7 \mathrm{sej} / \mathrm{g}$ & $2.11 \mathrm{E} 16 \mathrm{sej}$ \\
Maintenance cost & $1.10 \mathrm{E} 4 €$ & $1.4 \mathrm{E} 12 \mathrm{sej} / €$ & $1.54 \mathrm{E} 16 \mathrm{sej}$ \\
Plant construction cost* & $1.25 \mathrm{E} 5 €$ & $1.4 \mathrm{E} 12 \mathrm{sej} / €$ & $1.54 \mathrm{E} 16 \mathrm{sej}$ \\
Total emergy for coated & $2.39 \mathrm{E} 9 \mathrm{~g}$ & $1.43 \mathrm{sej} / \mathrm{g}$ & $3.42 \mathrm{E} 19 \mathrm{sej}$ \\
\multicolumn{1}{c}{ products } & & & \\
\hline
\end{tabular}

*Plant construction cost: in order to obtain the cost per year, it was assumed that the plant life is 20 years. The total cost for plant construction, 2.5E6, was then divided by 20 years

$(2.5 \mathrm{E} 6 / 20=1.25 \mathrm{E} 5 €)$.

column 3 is the transformity used for calculations, expressed in solar emergy joule per joule or other appropriate units (sej/€, sej/g); column 4 is the solar emergy of a given flow, calculated as the input times the transformity (column $2 \times$ column 3 ). The sum of all the solar emergy values in column 4 gives the total emergy flow for each process. On dividing this value by the quantity reported in column 2 , a new transformity is obtained (i.e. on dividing the total emergy flow of the foundry, 9.68E19 sej, by the quantity of billets produced, 7.14E9 g, the transformity of the billet is obtained). For each table (Tables 8, 9 and 10), a new transformity was obtained for the manufactured aluminium. It is possible to compare the transformity of raw aluminium (12.5E9 sej/g) with the transformity of the aluminium billets (1.35E10 sej/g, Table 8 ) coming out from the foundry, the transformity of the extrusion product (1.39 E10 sej/g, Table 9) and the transformity of the coated aluminium bars (1.43 sej/g, Table 10). As expected, the transformity value increases due to the energy flows involved in each process, as described in Fig. [3](renewable and non-renewable resources such as electricity, fuel, materials, human labour, water, oxygen, etc.). The most remarkable emergy flows are mainly associated with electricity and methane consumption and to the use of aluminium panels, due to the high solar emergy content of raw aluminium.

\section{CONCLUSION}

The application of the matrix method permits the company to evaluate the environmental protection indices (Ep, $Y_{L}, L_{i}$ ) but does not provide information on the environmental cost of the whole industrial process, in terms of use of resources (fuel, electricity, water, etc.). For this purpose, we recommend the application of emergy analysis as a complementary index for the global evaluation of sustainability. The integrated results of the two methodologies applied suggests that an effort towards the practice of energy recovery and the use of renewable resources can lead to socioeconomic savings and a more sustainable way of living. 
APPENDIX A: LIST OF REFERENCES FOR THE TRANSFORMITIES USED

$\begin{array}{ll}\text { Electricity } & =1.43 E 5 \mathrm{sej} / \mathrm{J}[11] \\ \text { Human labour } & =7.38 \mathrm{E} 6 \mathrm{sej} / \mathrm{J}[12] \\ \text { Methane } & =4.80 \mathrm{E} 4 \mathrm{sej} / \mathrm{J}[8] \\ \text { Oxygen } & =5.16 \mathrm{E} 7 \mathrm{sej} / \mathrm{g}[13] \\ \text { Money } & =1.4 \mathrm{E} 12 \mathrm{sej} / €[14] \\ \text { Water } & =3.40 \mathrm{E} 5 \mathrm{sej} / \mathrm{g}[15] \\ \text { Aluminium panels } & =12.53 \mathrm{E} 9 \mathrm{sej} / \mathrm{g}[10]\end{array}$

APPENDIX B: PROCEDURE FOR EMERGY CALCULATIONS IN TABLE 8

1. Electricity consumption $=526680 \mathrm{~kW} \mathrm{~h}=1.89 \mathrm{E} 12 \mathrm{~J}$ per year

The transformity is $1.43 \mathrm{E} 5 \mathrm{sej} / \mathrm{J}[11, \mathrm{p} .72]$.

2. Human labour $=2.8 \mathrm{E} 10 \mathrm{~J}$ per year 22 employees working $8 \mathrm{~h}$ per day correspond to 2628 persons/year $\times 2500 \mathrm{kcal} /$ person $\times 4186$ $\mathrm{J} / \mathrm{kcal}=2.8 \mathrm{E} 10 \mathrm{~J}$. The transformity is 7.38E6 sej/J [12].

3. Methane consumption $=891,660 \mathrm{~m}^{3}$ per year Multiplied by the heating capacity: $891,660 \mathrm{~m}_{\mathrm{n}}^{3} \times 39,830 \mathrm{~kJ} / \mathrm{m}_{\mathrm{n}}^{3}=3.5 \mathrm{E} 10 \mathrm{~kJ}$. The transformity is $4.8 \mathrm{E} 4 \mathrm{sej} / \mathrm{J}[8]$.

4. Recycled aluminium $=3580 \mathrm{t} / \mathrm{year}$ Transformity $=12.53 \mathrm{E} 9 \mathrm{sej} / \mathrm{g}[10]$.

5. Aluminium panels $=2494.8 \mathrm{t} /$ year Transformity $=12.53 \mathrm{E} 9 \mathrm{sej} / \mathrm{g}[10]$.

6. Aluminium scraps from billets $=1462.08 \mathrm{t} /$ year Transformity $=12.53 \mathrm{E} 9 \mathrm{sej} / \mathrm{g}[10]$.

7. Other materials:

Magnesium consumed $=1.15 \mathrm{E} 7 \mathrm{~g} /$ year; $\mathrm{Mg}$ cost $=0.0015 € / \mathrm{g} ; \mathrm{Mg}$ total cost $=17,325 € /$ year. Silicon consumed $=1.15 \mathrm{E} 7 \mathrm{~g} /$ year; Si cost $=0.0022 € / \mathrm{g}$; Si total cost $=25,410 € /$ year.

Total cost $=42,735 € /$ year for $2.30 \mathrm{E} 7 \mathrm{~g}$ of materials.

8. Water consumption $=3.2 \mathrm{E} 6 \mathrm{~kg} / \mathrm{year}$ Transformity $=3.4 \mathrm{E} 5 \mathrm{sej} / \mathrm{g}[15]$.

9. Oxygen consumption $=2,557,280 \mathrm{~kg} /$ year Transformity $=5.16 \mathrm{E} 7 \mathrm{sej} / \mathrm{g}[13]$

10. Maintenance costs $=9500 €$ per year The transformity is $1.4 \mathrm{E} 12 \mathrm{sej} / €$, according to Tiezzi's evaluation [14]: 7.26E8 sej/£× $1.93627 \mathrm{E} 3$ $£ / €(1 €=1.93627 £)$.

11. Plant building price $=€ 4,312,410 / 20=2.15 E 5 €$

The yearly cost was evaluated by dividing the total cost by 20 years (the average efficiency of the plant is estimated to be 20 years).

\section{REFERENCES}

[1] King, A.A. \& Lenox, M.J., Does it really pay to be green? Journal of Industrial Ecology, 5(1), pp. 105-115, 2001.

[2] Popp, J., Hoag, D. \& Hyatt, E., Sustainability indices with multiple objectives. Ecological Indicators, 1(1), pp. 37-47, 2001.

[3] Ribaudo, M.O., Hoag, D.L., Smith, M.E. \& Heimlich, R., Environmental indices and the politics of the Conservation Reserve Program. Ecological Indicators, 1(1), pp. 11-20, 2001. 
[4] Giannantoni, C., Cialani, C. \& Mansueti, A., Analysis of investments based on the trilateral externality approach (firm, citizen, state). Ecological Indicators, 2, pp. 27-38, 2002.

[5] Hoag, D.L., Ascough, J.C. \& Engler-Palma, A., The impact matrix approach and decision rules to enhance index dimensionality, flexibility and representation. Ecological Indicators, 2, pp. 161-168, 2002.

[6] Spangenberg, J.H., Environmental space and the prism of sustainability: frameworks for indicators measuring sustainable development. Ecological Indicators, 2(3), pp. 295-309, 2002.

[7] Siracusa, G., La Rosa, A.D. \& Sterlini, S.E., A new methodology to calculate the environmental protection index (Ep). A case study applied to a company producing composite materials. Journal of Environmental Management, 73, pp. 275-284, 2004.

[8] Odum, H.T., Environmental Accounting, John Willey \& Sons: New York, 1996.

[9] Ulgiati, S., Brown, M.T., Bastianoni, S. \& Marchettini, N., Emergy-based indices and ratios to evaluate the sustainable use of resources. Ecological Engineering, 5, pp. 519-531, 1995.

[10] Brown, M.T. \& Buranakarn, V., Emergy indices and ratios for sustainable material cycles and recycle options. Resources Conservation and Recycling, 38, pp. 1-22, 2003.

[11] Bastianoni, S., Marchettini, N., Principi, I. \& Tiezzi, E., Sviluppo di un modello di analisiemergetica per il sistema elettrico nazionale, Primo rapporto finale, Università di Siena, 2000.

[12] Ulgiati, S., Odum, H.T. \& Bastianoni, S., Emergy use, environmental loading and sustainability. An emergy analysis of Italy. Ecological Modelling, 73, pp. 215-268, 1994.

[13] Brown, M.T. \& Ulgiati, S., Emergy evaluations and environmental loading of electricity production systems. Journal of Cleaner Production, 10, pp. 321-334, 2002.

[14] Tiezzi, E. et al., Analisi di sostenibilità ambientale nella provincial di Modena e dei suoi distretti, Siena, 1998.

[15] Brown, M.T. \& Arding, J.E., Transformity working paper, 1991. 